\title{
NOTES
}

\section{ANTITRUST LAW: SUPREME COURT DEVELOPS PRE- SUMPTION OF ILLEGALITY IN APPLYING SECTION 7 OF THE GLAYTON ACT TO BANK MERGER}

T wo significant developments in antitrust law were marked by United States $v$. Philadelphia Nat'l Bank, ${ }^{1}$ in which the Supreme Court extended the scope of section 7 of the Clayton Act $^{2}$ to include bank mergers and formulated a simplified rule by which courts, in certain cases, may test the illegality of alleged violations of the section. The essence of this rule is that a rebuttable presumption of anticompetitiveness is raised where a merger "produces a firm controlling an undue percentage share of the relevant market, and results in a significant increase in the concentration of firms in that market."3

On February 24, 1961, the Comptroller of the Currency, pursuant to the provisions of the Bank Merger Act, ${ }^{4}$ approved the merger of The Philadelphia National Bank and Girard Trust Corn Exchange Bank, the second and third largest banks in the Philadelphia area. On the following day, the Justice Department instituted an action challenging the merger under section 1 of the Sherman Act $^{\tilde{\sigma}}$ and section 7 of the Clayton Act. ${ }^{\beta}$ The district coùrt upheld

\footnotetext{
2374 U.S. 321 (1963).
}

s 38 Stat. 731 (1914), as amended, 64 Stat. 1125 (1950), 15 U.S.C. $\$ 18$ (1958). The relevant portion of the statute reads as follows: "No corporation engaged in commerce shall acquire, directly or indirectly, the whole or any part of the stock or other share capital and no corporation subject to the jurisdiction of the Federal Trade Commis: sion shall acquire the whole or any part of the assets of another corporation engaged also in commerce, where in any hine of commerce in any section of the country, the effect of such acquisition may be substantially to lessen competition, or to tend to create a monopoly."

374 U.S. at 363 .

474 Stat. 129 (1960), as amended, 12 U.S.C. \$ 1828 (c) (Supp. IV, 1963). The act requires the approval of the Comptroller of the Currency for mergers where the resulting bank will be a national bank. The Comptroller is to consider various factors, including the effect on competition, to determine whether the merger will be in the public interest. In addition, reports on the competitive factors involved are required from the Attorney General, the Federal Reserve Board, and the Federal Deposit Insurance Corporation. In the instant case, the advisory report from each of the three agencies stated that the merger would have anticompetitive effects in the Philadelphia area.

50 Stat. 693 (1937), as amended, 15 U.S.C. $\S ~ I$ (1958).

- Sce note 2 supra. 
the merger on the grounds that section 7 was not applicable to bank mergers and that even if it were, this merger would not violate its provisions. ${ }^{7}$ The court held further that since there must be proof of a higher degree of anticompetitiveness under the Sherman Act than under the Clayton Act, a fortiori the former would not be violated.

On appeal, the Supreme Court reversed and remanded with directions to issue an injunction prohibiting the merger. After a preliminary sketch of the background of the case and of the banking industry, the Court held in a two stage opinion that section 7 was applicable to bank mergers and that the proposed merger would violate the statute.

The Court determined that the legislative history of the 1950 amendment to section 7 revealed that Congress intended to extend the scope of the section to include all forms of corporate combination. ${ }^{8}$ Furthermore, neither the unique nature of the banking industry nor the regulatory provisions of the Bank Merger Act gave the industry immunity from antitrust laws. ${ }^{\circ}$ Having thus decided on the applicability of section 7, the Court considered the legality of the merger under the statute. It held first, that banking would qualify as a line of commerce; ${ }^{10}$ second, that the four-county Philadelphia

7 United States v. Philadelphia Nat'1 Bank, 201 F. Supp. 348 (E.D. Pa. 1962).

${ }^{8} 374$ U.S. at 335-49. The reasoning of the Court was that although mergers could be classified neither as stock acquisitions nor as asset acquisitions, their exclusion from the coverage of the amended statute would defeat the intent of Congress. Morcover, to equate mergers and asset acquisitions would create a large loophole in an amendment designed to close loopholes, since banks do not fall under FTC regulation and only FTC-regnlated industries are covered in the asset clause. The solution, thercfore, was to construe the stock acquisition clause, which had been recnacted verbatim in the 1950 amendment, as being expanded to include mergers. Then both clauses, read together, would cover the entire spectrum of corporate combination. The only remaining exception, i.e., asset acquisitions involving firms not regulated by the FTC, would be relatively unimportant, since such combinations are either impractical, as in the case of banks, or covered by other statutes.

374 U.S. at $350-55$. To support tbis conclusion, the Court cited the wcll established rule that repeals of the antitrust laws by implication from regulatory statutes occur only where there is clearly a repugnancy between the two. See, e.g., Silver v. New York Stock Exch., 373 U.S. 341, 357 (1963); California v. FPC, 369 U.S. 482, 485 (1962); United States v. Borden Co., 308 U.S. 188, 198 (1939). The Court found no such repugnancy between $\$ 7$ and the Bank Merger Act, pointing out that the Comptroller did not have the authority to make final judgment as to the effect of a merger on competition and rejecting the contention that federal regulation of banking was so pervasive as to render it immune from the antitrust laws.

10374 U.S. at 356 . A determination of the relevant line of commerce (product market) and the relevant section of the country (geographic market) is prerequisite to the application of any test of illegality under $\$ 7$. United States v. E. I. du Pont de Nemours \& Co., 353 U.S. 586, 593 (1957). In the instant case, the Court avoided a 
area would be the relevant section of the country; $;^{11}$ and third, that since the resulting bank would control thirty percent of the banking business in the relevant area and the concentration of business in the two leading banks would be increased thirty-three per cent by the merger,"12 the combination was "so inherently likely to lessen competition substantially that it must be enjoined in the absence of evidence clearly showing that the merger is not likely to have such anticompetitive effects."13

lengthy discussion of the product market by agreeing with the lower court that commercial banking would clearly qualify as a line of commerce under the statute. For cases in which the determination of the relevant product market played an important part, see, e.g., Brown Shoc Co. v. United States, 370 U.S. 294 (1962); United States v. E. I. du Pont de Nemours \& Co., 351 U.S. 377 (1956); American Crystal Sugar Co. v. Cuban-American Sugar Co., 259 F.2d 524 (2d Cir. 1958); United States v. Bethlehem Steel Corp., 168 F. Supp. 576 (S.D.N.Y. 1958).

11374 U.S. at $357-62$. In the instant case, only the geographic market had to be considered at length. See note 10 supra. The Court determined the relevant area to be that in which the merger would have had a direct and immediate effect on competition, regardless of other areas in which the merging parties might do business or compete. Explicit in this determination was a concern for protection of the small businessman, who generally obtains credit from local banks, and who is a principal beneficiary of the antitrust laws. 374 U.S. 360-61 \& n.37. Also explicit was the admission that the four-county Philadelphia area was a workable compromise between markets either so large or so small as to make the statute meaningless. For other factors to be considered in defining the relevant market, sec, e.g., Standard Oil Co. v. United States, 337 U.S. 293, 299-300 \& n.5 (1949) (area of effective competition); United States v. Columbia Steel Co., 334 U.S. 495, 529 (1948) (transportation costs); American Crystal Sugar Co. v. Cuban-American Sugar Co., supra note 10, at 528-29 (natural selling area).

In Brown Shoe Co. v. United States, supra note 10 , at 325 , it was stated that each relevant market may have certain readily definable submarkets and that anticompetitiveness in any one would constitute a violation of $\$ 7$. No reference to submarkets was made, however, in the instant case, despite the obvious utility of the concept in disposing of appellee's strong contention for a more broadly defined market. Brief for Appellee, pp. 47-52. The government's success, even without the use of this approach seems to indicate that an antitrust plaintiff will benefit from the flexibility of definition of the relevant market.

12 374 U.S. at 364-65 \& nn.41-42. The Court relied on a recommendation of Congress that the tests of illegality under $\S 7$ be patterned after tests in other sections of the Clayton Act. See H.R. ReP. No. 1191, 81st Cong., 1st Sess. 8 (1949). Using this approach, it examined the percentages of market share and concentration found in such cases. E.g., Standard Oil Co. v. United States, supra note 11 ( 33 of the Clayton Act); Standard Fashion Co. v. Magrane-Houston Co., 258 U.S. 346 (1952) ( $\$ 3$ of the Clayton Act). The Court also examined the tests used under other statutes. E.g., FTC v. Motion Picture Advertising Serv. Co., 344 U.S. 392 (1953) ( 1 of the Sherman Act and $\$ 5$ of the Federal Trade Commission Act).

In addition, the Court considered the recommendations of several economic and legal commentators. E.g., Kaysen \& TuRner, ANtrTrust POLICY 133 (1959); Bok, Section 7 of the Clayton Act and the Merging of Law and Economics, 74 HARv. L. REv. 226 at 308-16, 328 (1960); Markham, Merger Policy Under the New Section 7: A SixYear Appraisal, 43 VA. L. REv. 489, 521-22 (1957); Stigler, Mergers and Preventive Antitrust Policy, 104 U. PA. L. REv. 176, 182 (1955).

${ }^{13} 374$ U.S. at 363 . In view of these conclusions, the Court considered it unnecessary 
The instant case will have an important and immediate effect on the commercial banking industry. ${ }^{14}$ However, since the determina. tion that section 7 applies to bank mergers was based largely upon interpretation of the intent of Congress, little seems to be gained by discussion on this point. Suffice it to say that there is substantial disagreement with the Court's conclusion. ${ }^{15}$

Section 7 of the Clayton Act as originally enacted was designed to curtail anticompetitive acts in their incipiency before they reached Sherman Act proportions. ${ }^{16}$ The courts, however, construed it to

to examine the status of the merger under the Sherman Act. Mr. Justice Harlan, joined by Mr. Justice Stewart, dissented, saying that Congress did not intend to include bank mergers under the amended $\S 7$ and that to do so would nullify the Bank Merger Act. Following the majority, he declined to reach the Sherman Act question. 374 U.S. at 373-96. Mr. Justice Goldberg, in a separate opinion, agreed with Justice Harlan as to the applicability of $\S 7$ to bank mergers, but felt that there might be a substantial Sherman Act question, on which he reserved consideration. 374 U.S. at 396-97. For a recent case involving the status of bank mergers under the Sherman Act, see United States v. First Nat'l Bank \& Trust Co., 208 F. Supp. 457 (E.D. Ky. 1962), prob. juris. noted, 374 U.S. 824 (1963) (upholding a merger which produced a bank controlling $79.62 \%$ of the market share of trust business and $52.70 \%$ of the banking assets in the county).

${ }^{11}$ It is obvious that future plans for expansion will have to be considered in light of this decision, and no important bank mergers should be attempted without careful analysis of the relevant antitrust factors. Such analysis will be complicated by the variety of state branch banking laws. Compare N. C. GEN. STAT. \$ 53.62 (1960) zuith Fla. Stat. ANN. \$ 659.06 (Supp. 1962) and HawaII Rev. Laws $\$ 178-39$ (Supp. 1961). It is not clear what effect these laws will have on the determination of the relevant market. See the recent approval by the Comptroller of the merger between CrockerAnglo National Bank (San Francisco) and Citizens National Bank (Los Angeles), 32 U.S.L. WeER 2165 (Oct. 8, 1963).

Further legislation would be helpful in defining the position of the industry in light of the instant case. For example, the addition of an express savings clause to the Bank Merger Act, codifying the Philadelphia Bank holding, might clarify the interrelation between that act and the antitrust laws. For further clarification, a section could be added outlining a national banking policy, similar to the statement of the national transportation policy which is iuserted at the beginning of tbe Interstate Commerce Act. 54 Stat. 899 (1940), as amended, 49 U.S.C. I preceding $\$ 1$ (1958). Sce also McLean Trucking Co. v. United States, 321 U.S. 67, 85-86 (1944).

The statute might also be amended to exempt banking from the antitrust laws in certain cases. For example, situations may arise calling for immediatc expausion of banking facilities to attract industry to a relatively underdeveloped arca or to provide local funds for a growing local industry. In such a case, if expansion by other means were impractical, expansion by merger might be allowed. Similar factors are, of course, considered by the Comptroller under the present act, but the instant decision would make it necessary to expressly provide for exemption.

${ }^{15}$ See note 13 supra. For opinions to the effect that $\$ 7$ does not apply to bank mergers, see Bcrle, Banking Under the Antitrust Laws, 49 Colum. L. Rev. 589 (1949); Fiechter, Another Year of American Antitrust Law Regarding Bank Mergers, 17 Bus. LAw. 906 (1962); Wemple \& Cutler, The Federal Bank Merger Law and the Antitrust Laws, 16 BUS. LAw. 994 (1961); Comment, 71 YALE L.J. 502 (1962). But sce 64 HARv. L. REv. 1212 (1951); 37 N.Y.U.L. REv. 735 (1962).

${ }^{16}$ See United States v. Bethlehem Steel Corp., I68 F. Supp. 576, 582 (S.D.N.Y. 
apply only to limited cases of stock acquisitions and even then in a manner tending to retain Sherman Act standards. ${ }^{17}$ Consequently, Congress amended the section in 1950 in order to broaden its scope: and increase its effectiveness. 18

It is in the context of the test of illegality that the instant case has its primary effects upon antitrust law. Two principal methods of approach have developed in regard to the standard of illegality under the Glayton Act. ${ }^{19}$ First, the qualitative approach favors a detailed analysis of economic data to determine the probable effect of the merger. ${ }^{20}$ The quantitative approach, on the other hand, emphasizes such factors as percentage of market share and absolute dollar amounts of sales or assets in establishing a prima facie case of probable lessening of competition. ${ }^{21}$ It is impossible to detect a clear trend toward either approach from the cases in which section 7 or other sections of the Clayton Act have been involved. ${ }^{22}$ In fact,

1958). The relevant portion of the original $\$ 7$ read as follows: "no corporation engaged in commerce shall acquire, directly or indirectly, the whole or any part of the stock or other share capital of another corporation engaged also in commerce, where the effect of such acquisition may be to substantially lessen competition between the corporation whose stock is so acquired and the corporation making the acquisition, or to restrain such commerce in any section or community, or tend to create a monopoly of any line of commerce." Clayton Act, ch. 323, § 7, 38 Stat. 731 (1914).

${ }^{17}$ See note 19 infra. See United States v. Columbia Steel Co., 334 U.S. 495 (1948); Arrow-Hart \& Hegeman Elec. Co. v. FTC, 291 U.S. 587 (1934); United States v. Celanese Corp. of America, 91 F. Supp. 14 (S.D.N.Y. 1950),

${ }^{18}$ For analysis of the legislative history of the 1950 amendment see Brown Shoe Co. v. United States, 370 U.S. 294, 311-23 (1962); United States v. Bethlehem Steel Corp., 168 F. Supp. 576, 581-83 (S.D.N.Y. 1958); Note, 52 Colum. L. REv. 765 (1952).

${ }^{10}$ Prior to 1950, the Sherman Act test of illegality, known as the rule of reason, was applied in $\$ 7$ cases. Under this rule, the alleged violation must have been unreasonable and its actual effects on competiton proved. See, e.g., International Shoe Co. v. FTC, 280 U.S. 291 (1930); Temple Anthracite Coal Co. v. FTC, 51 F.2d 656 (3d Cir. 1931); V. Vivaudou, Inc. v. FTC, 54 F.2d 273 (2d Cir. 1931); United States v. Republic Steel Corp., 11 F. Supp. 117 (N.D. Ohio 1935). But see Aluminum Co. of America v. FTC, 284 Fed. 401 (3d Cir. 1922). Congress apparently rejected this test in adopting the 1950 amendment to the Clayton Act. See United States v. Bethlehem Steel Corp., 168 F. Supp. 576 (S.D.N.Y. 1958). However, the term "rule of reason" is still used in the present controversy between qualitative and quantitative approaches to $\$ 7-$ not in the Sherman Act sense, but as synonomous with qualitative proof of probable lessening of competition. See Handler \& Robinson, A Decade of Administration of the Celler-Kefauver Antimerger Act, 61 Colum. L. Rev. 629 (1961); Implica. tions of Brown Shoe for Merger Law and Enforcement, 8 ANTixRust BuLx. 225 (1963); Comment, 58 Colum. L. REv. 1269 (1958).

${ }^{\circ 0}$ See, e.g., Pillsbury Co., TRAdE Reg. ReP. I 29277 (FTC Order Dec. 16, 1960).

${ }^{21}$ See, e.g., Standard Oil Co. v. United States, 337 U.S. 293 (1949); Hamilton Watch Co. v. Benrus Watch Co., 114 F. Supp. 307 (D. Conn.), affd, 206 F.2d 738 (2d Cir. 1953).

2 See generally Barnes, The Primacy of Competition and the Brown Shoe Decision, 51 GEO. L.J. 706 (1963); Handler \& Robinson, supra note 19; Lewyn \& Mann, Ten Years Under the New Section 7 of the Clayton Act: A Lawyer's Practical Approach to the Case Law, 36 N.Y.U.L. REv. 1067 (1961); Markham, supra note 12. 
many decisions have been based on a combination of qualitative and quantitative factors. ${ }^{23}$

The Supreme Court first examined the amended section 7 in Brown Shoe, ${ }^{24}$ in which it affirmed the lower court decision enjoining the proposed merger between the third and eighth largest firms in the shoe industry. The Court pointed out that the pervading theme behind the 1950 amendment was' a fear of increasing concentration in American industry. ${ }^{25}$ Although Congress had specified no definite qualitative or quantitative tests by which to measure this concentration, it had indicated that each merger must be viewed functionally in the context of the industry involved.20 On this basis the Court adopted a qualitative approach, considering such factors as the nature of the industry, the history of concentration in the industry, and the ultimate purpose of the merger. ${ }^{27}$ Significantly, there seemed to be no substantial factors present upon which a quantitative test could be constructed;28 however, such an approach was not foreclosed to future cases. ${ }^{20}$

In Philadelphia Bank, the Court seized its first opportunity to apply a quantitative test of illegality by forging the substantial percentages available into a rebuttable presumption of violation of section 7.30 While the instant case merely echoed the Brown Shoe analysis of the statutory test, especially as to the concern with the

${ }^{23}$ E.g., United States v. E. I. du Pont de Nemours \& Co., 353 U.S. 586 (1957) (market share, purpose of acquisition); Crown Zellerbach Corp. v. FTC, 296 F.2d 800 (9th Cir. 1961) (dominance of acquiring firm); United States v. Koppers Co., 202 F. Supp. 437 (W.D. Pa. 1962) (market share, elimination of substantial competition, concentration in leading firms); United States v. Bethlehem Steel Corp., 168 F. Supp. 576 (S.D.N.Y. 1958) (rejects qualitative-quantitative dichotomy as a war of words, but considers a number of varied factors).

24 Brown Shoe Co. v. United States, 370 U.S. 294 (1962). Only two other cases involving the amended $\S 7$ had come before the Court, and in neither case did the Court find it necessary to analyze the statute. Jerrold Electronics Corp. v. United States, 365 U.S. 567 (1961); Maryland \& Virginia Milk Producers Ass'n v. United States, 362 U.S. 458 (1960).

${ }^{25}$ Brown Shoe Co. v. United States, supra note 24, at 315.

${ }^{36} I d$, at $321-22$.

in Id. at 329,344 .

sa Id. at 302, 303,329, 347-53. Brown Shoc Co., one of the participants, manufactured $4 \%$ of the nation's shoes. Kinney, the other participant, manufactured $0.5 \%$. The market share of the merged firm in selected cities varied widely from $5.1 \%$ to $57.7 \%$.

${ }^{29} \mathrm{Id}$. at 329 . It is significant to note that Philadelphia Bank, despite its acceptance of a quantitative analysis, also left the way open for consideration of qualitative factors where appropriate. The Court stated that the test it adopted was applicable only to inherently suspect mergers. 374 U.S. at 363 .

${ }^{80}$ See note 12 supra and accompanying text. 
trend toward concentration, ${ }^{31}$ it attained independent stature in section 7 interpretation through its treatment of the quantitative approach. Both cases taken together seem to indicate that the Supreme Court has exclusively embraced neither the qualitative nor the quantitative approach, but will effectively utilize either one, depending on the fact situation at hand.

Thus we come to an examination of the presumption rule itself. Two elements are to be considered-the market share controlled by the merged firm and the concentration of market share in the leading firms of the industry. ${ }^{32}$ No clues are given as to the relative importance of each. In fact, the Court repeatedly refers to "these percentages," implying that the two are inseparable. The more meaningful figure, however, is market control in the resulting firm, expressed as a percentage share of the relevant market. It is more precise than concentration in the leading firms. For example, in determining the percentage of concentration, it is not at all clear how many firms are to be considered in arriving at the necessary figure. ${ }^{33}$

Moreover, interesting problems will arise when one of the percentage figures is extremely high or low in comparison with the other or when both are at a level somewhere between the instant case and Brown Shoe. The Court had no occasion to set a percentage limit, below which no presumption of anticompetitiveness will arise. ${ }^{34}$ Therefore, it is not clear at what point the Court in future cases will shift from a Philadelphia Bank to a Brown Shoe analysis.

Another problem in regard to the presumption is that, despite the Court's language, it would seem to be a per se rule in practical effect. Very few opportunities for rebuttal are left open to future defendants in similar cases, particularly in bank merger cases. ${ }^{35}$ The

\footnotetext{
31370 U.S. at $355,362-63$.

${ }^{32}$ Sec note 12 supra and accompanying text.

${ }^{33}$ In the instant case, concentration in the two leading firms was considered. 374 U.S. at 365. A study of other cases will show, however, that the number of firms will vary widely. See, e.g., Brown Shoe Co. v. United States, 370 U.S. 294 (1962) (top four and top twenty-four); FTC v. Motion Picture Advertising Serv. Co., 344 U.S. 392 (1953) (top four); United States v. Koppers Co., 202 F. Supp. 437 (W.D. Pa. 1962) (top four and top twenty); United States v. Bethlehem Steel Corp., 168 F. Supp. 576 (S.D.N.Y. 1958) (top two and top four).

374 U.S. at $364-65$.

${ }^{35} I d$. at 366-71. The Court rejected the arguments that there are sufficient alternatives for dissatisfied customers after the merger, that the unique nature of the banking industry renders it immune from the anticompetitive effects of mergers and that the ultimate benefit to the community outweighs antitrust considerations. In addition, it
} 
presentation of positive proof that a merger will increase and not lessen competition is, of course, not foreclosed, but the Court's summary rejection of the testimony of the banks' witnesses in the instant case provides little encouragement for future defendants. ${ }^{30}$ Two distinct possibilities for a valid defense are mentioned, however, both in Philadelphia Bank and in Brown Shoe. These are the doctrines of the failing company ${ }^{37}$ and countervailing power, ${ }^{38}$ neither of which was considered applicable to the instant situation. Nevertheless, the emphasis placed on them by the courts may herald the tone of arguments by future antitrust defendants.

The immediate effect of the Philadelphia Bank decision will be twofold. First, many mergers which might otherwise have been consummated without challenge will die a-borning. Certainly the legal and business worlds will take notice of the results of this case when considering mergers of similar proportions. Second, in those cases which do reach the courts, the Justice Department and other plaintiffs will wield a powerful weapon, since the burden of proof on the issue of probable substantial lessening of competition may be shifted

voiced a basic premise of antitrust law: that internal expansion through de novo branches is socially more desirable than expansion by merger.

${ }^{38}$ There was a divergence of views between the lower court and the Supreme Court as to the validity of the testimony presented. The district court spoke of "experienced, substantial bankers [who] have unanimously demonstrated that the proposed merger would not cause an undue concentration of banking," while the Supreme Court dismissed the same testimony as lay evidence. Compare 201 F. Supp. at 371 with 374 U.S. at 366-67.

37 374 U.S. at $371-72$ \& n.46; 370 U.S. at 331. The failing company doctrine proposes as a justification of a merger the fact that the acquired firm is near bankruptcy. I11 the instant case, it was conceded that both banks were in sound financial condition; therefore the doctrine was inapplicable. The doctrine originated in International Shoe Co. v. FTC, 280 U.S. 291 (1930), and has been mentioned in a number of later cases, most of which have held it to be inapplicable. See, e.g., Crown Zellerbach Corp. v. FTC, 296 F.2d 800 (9th Cir. 1961); Erie Sand \& Gravel Co. v. FTC, 291 F.2d 279 (3d Cir. 1961). But see Maryland \& Virginia Milk Producers Ass'n v. United States, 167 F. Supp. 799 (D.D.C. 1958), aff'd, 362 U.S. 458 (1960).

${ }^{38} 374$ U.S. at $370 ; 370$ U.S. at 331 . The doctrine of countervailing power allows two small companies to merge to enable themselves to compete with the industry leader. See, e.g., Standard Oil Co. v. United States, 337 U.S. 293 (1949); American Crystal Sugar Co. v. Cuban-American Sugar Co., 152 F. Supp. 387 (S.D.N.Y. 1957), aff'd, 259 F.2d 524 (2d Cir. 1958); United States v. Bethlebem Steel Corp., 168 F. Supp. 576 (S:D.N.Y. 1958); United States v. Republic Steel Corp., 11 F. Supp. 117 (N.D. Ohio 1935). The Court in the instant case felt first that the participating banks were not "small companies" and second that the doctrine would be misapplied in this fact situation, since the industry leaders here, the New York banks, were actually in a larger market area, distinct from that in which anticompetitive effects were felt. The most conspicuous example of the application of this doctrine to allow large mergers is. the government's agreement not to prosecute the Nash-Hudson, Kaiser-Willys, and Studebaker-Packard mergers in the automobile industry. 
to the defendant. It is interesting to note that the Court expressed a desire in both Brown Shoe and Philadelphia Bank for simplification of the qualitative proof necessary on this issue. ${ }^{39}$ However, it seems that the only definite guidelines for simplification have been addressed to the benefit of plaintiffs, not defendants. ${ }^{40}$ Therefore, when the presumption operates to shift the burden of qualitative proof to the defendant, he may be doubly burdened unless future decisions present similar guidelines on his behalf.

It is evident that the Supreme Court has laid some foundations for interpretation of the amended section 7. However, the full strength of the statute as applied to mergers will not be seen until the lower limits of the presumption rule are tested and the Court examines a wide sample of attempted rebuttals. ${ }^{41}$

\footnotetext{
${ }^{38} 374$ U.S. at $362 ; 370$ U.S. at 341 .

10 370 U. S. at 341 .

¿The Court will soon have an opportunity to examine further aspects of $\S 7$. See United States v. Continental Can Co., Trade REg. Rep. (1963 Trade Cas.) II 70759 (S.D.N.Y. 1963), prob. juris. noted, 32 U.S.L. WEER 3163 (U.S. Oct. 29, 1963); United States v. Aluminum Co. of America, 214 F. Supp. 501 (N.D.N.Y. 1963); prob. juris noted, 32 U.S.L. WEEK 3137 (U.S. Oct. 15, 1963); United States v. El Paso Natural Gas Co., Trade Reg. Rep. (1962 Trade Cas.) If 70571 (D. Utah 1962), prob. juris noted, 31 U.S.L. WEEK 3989 (U.S. MaY 28, 1963).
} 